\title{
Poststroke Dementia
}

\author{
H. Hénon ${ }^{a}$ F. Pasquier ${ }^{b}$ D. Leys ${ }^{a}$ \\ ${ }^{a}$ Department of Neurology, Stroke Unit, and ${ }^{b}$ Department of Neurology, Memory Center, \\ Lille University Hospital, Lille, France
}

\section{Key Words}

Poststroke dementia $\cdot$ Alzheimer's disease $\cdot$ Vascular dementia $\cdot$ White matter changes

\begin{abstract}
The association between stroke and dementia is frequent. The prevalence of poststroke dementia (PSD) ranges from 6 to $32 \%$, depending on the population studied, the criteria used for the diagnosis of dementia, and the time interval between the stroke and the neuropsychological assessment. The risk of PSD is high immediately after stroke and remains higher than in controls in stroke patients nondemented 3 months after stroke. Not all cases of PSD are vascular in origin, with about one third of demented patients diagnosed as having Alzheimer's disease plus stroke. The pathophysiology of PSD is probably multifactorial, with an influence of vascular lesions, associated Alzheimer's lesions and white matter changes. The risk of dementia is higher in older patients and in patients with preexisting cognitive decline - no dementia, severe stroke, a history of stroke, white matter changes and cerebral atrophy. The influence of stroke location, vascular risk factors and silent infarcts remains to be determined. PSD adversely influences the outcome in stroke patients.
\end{abstract}

Copyright @ 2006 S. Karger AG, Basel
The association between stroke and dementia is frequent. Poststroke dementia (PSD) has been an emerging field of research over the last decade, the term 'PSD' including any type of dementia occurring after a stroke, irrespective of its presumed cause.

\section{Epidemiology of PSD}

\section{Prevalence}

The prevalence of dementia in stroke survivors varies depending on the population studied, the criteria used for the diagnosis of dementia and the time interval between the stroke and the neuropsychological assessment. In population-based studies [1,2], the prevalence of dementia in subjects with a history of stroke was about $30 \%$, with a relative risk compared to stroke-free subjects ranging from 3.6 to 5.8. In hospitalized stroke patients $\geq 70$ years the prevalence of dementia was $28 \% 1.5$ years after stroke, with a relative risk of 4.7 compared to the controls, the relative risk being 4.8 in patients $\geq 80$ years and 6.7 in patients $<80$ years [3]. In cohorts of hospitalized stroke patients [4-18], the prevalence of PSD ranged from 6.2 to $32 \%$ (table 1). These discrepancies may be related to methodological differences [19]: the exclusion of aphasic patients or patients unable to undergo neuropsychological testing leads to a risk of underestimation of the prevalence of dementia [7,20], while the lack of systematic research into cognitive disturbances existing prior to the

\section{KARGER \\ Fax +4161306 1234 E-Mail karger@karger.ch} www.karger.com
Hilde Hénon, MD

Department of Neurology, Stroke Unit

Roger Salengro Hospital, CHRU de Lille

FR-59037 Lille (France)

Tel. +33 3204468 14, Fax +33 3204460 28, E-Mail hhenon@chru-lille.fr 
Table 1. Prevalence of PSD: literature data

\begin{tabular}{|c|c|c|c|c|}
\hline $\begin{array}{l}\text { Time interval } \\
\text { after stroke }\end{array}$ & $\begin{array}{l}\text { Prevalence } \\
\%\end{array}$ & $\begin{array}{l}\text { Criteria used for the diagnosis of } \\
\text { dementia }\end{array}$ & Population characteristics & Reference \\
\hline $7-10$ days $[4]$ & 16.3 & Clinician's opinion & $\begin{array}{l}\text { Ischemic stroke } \\
\text { Age } \geq 60 \text { years }\end{array}$ & \\
\hline 1 month & 32 & Mattis Dementia Rating Scale score & $\begin{array}{l}\text { First-ever stroke } \\
\text { Age } 60-80 \text { years }\end{array}$ & Andersen et al. [6], 1996 \\
\hline \multirow[t]{10}{*}{3 months } & 5.9 & NINDS-AIREN criteria & $\begin{array}{l}\text { Stroke } \\
\text { Exclusion of patients with previous } \\
\text { functional deficit }\end{array}$ & Madureira et al. [13], 2001 \\
\hline & 9.2 & ICD-10 criteria & $\begin{array}{l}\text { Ischemic stroke } \\
\text { Exclusion of patients with previous TIA }\end{array}$ & Lin et al. [14], 2003 \\
\hline & 13.6 & NINDS-AIREN criteria & First-ever ischemic stroke & Censori et al. [7], 1996 \\
\hline & $\begin{array}{l}26.3 \text {, relative risk com- } \\
\text { pared to controls }=9.2\end{array}$ & DSM-III-R criteria & $\begin{array}{l}\text { Ischemic stroke } \\
\text { Age } \geq 60 \text { years }\end{array}$ & Tatemichi et al. [5], 1992 \\
\hline & 26.3 & DSM-III-R criteria & $\begin{array}{l}\text { Ischemic stroke } \\
\text { Age } \geq 60 \text { years }\end{array}$ & Desmond et al. [11], 2000 \\
\hline & 22.1 & DSM-IV criteria & $\begin{array}{l}\text { Stroke } \\
\text { Age } \geq 18 \text { years }\end{array}$ & Barba et al. [10], 2000 \\
\hline & 31.8 & DSM-III criteria & $\begin{array}{l}\text { Ischemic stroke } \\
\text { Age } 55-85 \text { years }\end{array}$ & $\begin{array}{l}\text { Pohjasvaara et al. [9], } \\
1998\end{array}$ \\
\hline & 15.5 & DSM-IV criteria & $\begin{array}{l}\text { Stroke } \\
\text { Age } \geq 60 \text { years }\end{array}$ & Tang et al. [16], 2004 \\
\hline & 13.3 & $\begin{array}{l}\text { Clinical dementia rating scale } \\
\text { score } \geq 1\end{array}$ & $\begin{array}{l}\text { Ischemic stroke associated with small } \\
\text { vessel disease }\end{array}$ & Mok et al. [15], 2004 \\
\hline & 27.2 & DSM-IV criteria & $\begin{array}{l}\text { Ischemic stroke } \\
\text { Age } \geq 55 \text { years }\end{array}$ & Zhou et al. [17], 2004 \\
\hline \multirow[t]{3}{*}{6 months } & 22.8 & ICD-10 criteria & $\begin{array}{l}\text { Stroke } \\
\text { Age } \geq 40 \text { years }\end{array}$ & Hénon et al. [12], 2001 \\
\hline & 26 & Mattis Dementia Rating Scale score & $\begin{array}{l}\text { First-ever stroke } \\
\text { Age } 60-80 \text { years }\end{array}$ & Andersen et al. [6], 1996 \\
\hline & 8.5 & DSM-IV criteria & $\begin{array}{l}\text { First-ever ischemic stroke } \\
\text { Age } \geq 40 \text { years } \\
\text { MMS } \geq 15 \text { at the acute stage }\end{array}$ & Rasquin et al. [18], 2004 \\
\hline \multirow[t]{3}{*}{1 year } & 16.8 & $\begin{array}{l}\text { Proxy-informant interview based on } \\
\text { ICD-10 criteria }\end{array}$ & Stroke & Inzitari et al. [8], 1998 \\
\hline & 21.4 & ICD-10 criteria & $\begin{array}{l}\text { Stroke } \\
\text { Age } \geq 40 \text { years }\end{array}$ & Hénon et al. [12], 2001 \\
\hline & 10 & DSM-IV criteria & $\begin{array}{l}\text { First-ever ischemic stroke } \\
\text { Age } \geq 40 \text { years } \\
\text { MMS } \geq 15 \text { at the acute stage }\end{array}$ & Rasquin et al. [18], 2004 \\
\hline 1.5 years $[3]$ & 28 & DSM-III-R criteria & $\begin{array}{l}\text { Stroke } \\
\text { Age } \geq 70 \text { years }\end{array}$ & \\
\hline 2 years & 21.6 & ICD-10 criteria & $\begin{array}{l}\text { Stroke } \\
\text { Age } \geq 40 \text { years }\end{array}$ & Hénon et al. [12], 2001 \\
\hline 3 years & 19.2 & ICD-10 criteria & $\begin{array}{l}\text { Stroke } \\
\text { Age } \geq 40 \text { years }\end{array}$ & Hénon et al. [12], 2001 \\
\hline
\end{tabular}

TIA $=$ Transient ischemic attack; MMS = Mini Mental State 
Fig. 1. Incidence of PSD at different time intervals after stroke onset.

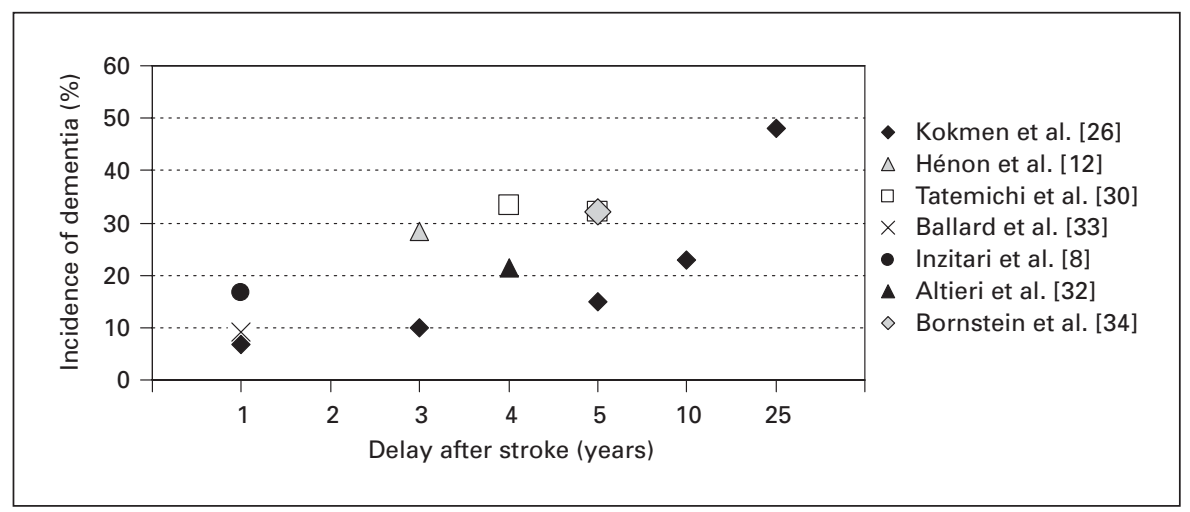

stroke entails a risk of overestimation of the incidence of $\mathrm{PSD}$, as prestroke dementia is frequent [21-25] and often undiagnosed [21].

\section{Incidence}

In a population-based study [26] conducted over a 25 year period, the cumulative incidence of PSD was $7 \%$ at 1 year, $10 \%$ at $3,15 \%$ at $5,23 \%$ at 10 years and increased to $48 \%$ at year 25 . Compared to the stroke-free subjects, the relative risk of dementia was 8.8 one year after stroke, 4.5 at 3 years, 3.5 at $5,2.5$ at 10 years and decreased to 2.0 at the end of the follow-up period. In another study [27] conducted in initially nondemented subjects $\geq 75$ years the relative risk of dementia after 3 years was 1.7 in patients with a history of stroke compared to the controls, the prior stroke being particularly potent when it had occurred within the preceding 3 months. In a more recent population-based study [28], a stroke doubled the risk of dementia uniformly over the 10-year study period, after a strict exclusion of patients with prestroke dementia. Only 1 community-based study [29] did not find strokes to be associated with a higher risk of dementia. However, this study was conducted in nonaphasic patients with a mild-to-moderate first-ever stroke and evaluated the risk of progressive dementia within 1 year.

Other studies were conducted in hospitalized stroke patients [12, 30-34]. Some of them [30-33] evaluated the incidence rate of PSD in patients not demented at months 3 or 6 , the incident cases of dementia actually corresponding to delayed dementia occurring some months after the index stroke. The incidence rate of delayed PSD was $33.3 \%$ after 52 months of follow-up, with a relative risk of 5 compared to the controls [30]. Similar results, with a relative risk of 6 and a cumulative risk of dementia yielding almost $50 \%$ at year 9 , were obtained in another study including the cohort of Tatemichi et al. [30] and a second group of patients assembled later [31]. Other studies conducted in patients nondemented at month 3 found delayed PSD in $9 \%$ of patients $\geq 75$ years within 1 year [33] and in $21 \%$ of stroke patients [32] within 4 years after stroke. The risk of delayed dementia was however much lower in the Lille stroke/dementia cohort, as only $6 \%$ of the patients who were not demented 6 months after stroke developed new onset dementia within 3 years [12]. The crude incidences of PSD in different studies are shown in figure 1 .

From all these data we can conclude that the risk of PSD is high and that it is highest in the first months after stroke: about one fifth of stroke patients are demented in the first months following stroke, with consequences in terms of health care and cost evaluation. With respect to the risk of delayed PSD the data also suggest that stroke patients remain at a higher risk of dementia than strokefree subjects do.

\section{Risk Factors of PSD}

\section{Patients' Characteristics}

Demographic Variables

Increasing age is clearly a risk factor of PSD $[4-14,17$, $18,26,30-32,35-37]$, the impact of stroke, however, being higher in younger patients [26, 28]. In most studies no influence of gender was observed [4, 5, 7, 9, 10-12, 14 , $16,17,30-32,35-37]$, while the data concerning the education level are controversial $[4,7,9,10-14,16-18,30$, $31,35-37]$.

Prestroke Functional Status and Cognitive Decline

The risk of PSD is higher in patients with a lower prestroke functional status $[4,6,8,10,16]$ and prestroke cognitive decline/no dementia $[10,12,15,16]$. 


\section{Stroke Characteristics}

\section{Stroke Subtype}

The risk and severity of cognitive disturbances occurring after a stroke do not seem to be influenced by the stroke type (ischemic or hemorrhagic) [10, 12, 13, 32].

\section{Stroke Severity}

The stroke severity influences the risk of PSD diagnosed soon after stroke. PSD diagnosed 3 months after stroke was more frequent in patients with a severe initial clinical deficit [7, 9-11, 14, 16, 35, 37]. The severity of the initial clinical deficit was also a predictor of PSD within 1 [8] and 3 years after stroke, with most cases of dementia occurring in the first months following stroke [12] However, although the total volume of cerebral infarction is probably important, no threshold has been identified yet, as the volume of functional tissue loss may be more important [38]. The influence of stroke severity on delayed dementia is not obvious, and no relationship between stroke severity and risk of delayed dementia has been demonstrated yet $[31,32]$.

\section{Stroke Location}

The influence of the location of the vascular lesion remains to be determined. A role of the left hemisphere has been suggested [7-9, 14, 17, 35]. PSD was also found to be more frequent in patients with a hemispheric stroke compared to brainstem/posterior fossa lesions and in patients with a pooled anterior/posterior cerebral artery stroke compared to other locations [11]. On the other hand, many studies did not find any relationship between stroke location and risk of PSD $[8,10,12,13,18,26,28$, $31,32]$. In a population of stroke patients $\geq 75$ years, none of the patterns of cerebrovascular disease highlighted as essential for the diagnosis of probable vascular dementia (VaD) by the NINDS AIREN criteria [39] was significantly different between stroke patients with or without PSD [40].

Only 1 study [37] has evaluated magnetic resonance imaging correlates of PSD, taking into account the volume, location and number of lesions. The conclusions suggest an influence of the lesions located in the left anterior corona radiata, part of the thalamocortical connection, and an influence of the total volume and number of infarcts. In this study larger volumes of right-sided infarcts (any infarct, frontal lobe and middle cerebral artery areas), and a larger volume (corona radiata, anterior centrum semiovale) and number (any infarct, deep posterior cerebral artery areas, pons, pallidum and anterior corona radiata) of infarcts on the left hemisphere were more fre- quent in patients with PSD. The authors however conclude that dementia occurring after first-ever stroke is not solely due to a single stroke but a combination of infarct features (volume, location and number), the extent of white matter changes (WMC), medial temporal lobe atrophy (MTLA) and host factors.

\section{Stroke Cause}

No influence of the etiology of stroke determined according to the TOAST criteria [41] has been reported [7, $9,11,12,14,31]$. However, in the Framingham study [28] strokes of atherothrombotic origin (including largeartery and lacunar infarcts and infarcts of unknown origin) doubled the risk of dementia compared to stroke-free subjects, while cardioembolic strokes did not increase the risk. Moreover, some data suggest that the risk of PSD could be lower in patients with a lacunar stroke than in those with a large arterial one $[4,11,15,18]$.

\section{Vascular Risk Factors}

The limited influence of well-established vascular risk factors such as hyperlipemia, arterial hypertension, tobacco and alcohol consumption on PSD is remarkable [4, $7-14,16,17,26,31,32,35]$. However, the contribution of arterial hypertension to PSD might be masked by its significant contribution to strokes. The data concerning the influence of diabetes mellitus [4, 7-17, 26, 31, 32, 35] and atrial fibrillation $[4,7-12,16,17,26,31,32,35,36]$ are controversial.

\section{Previous Stroke and Stroke Recurrence}

Previous stroke as well as stroke recurrence have been found to be associated with a higher risk of PSD in some $[4,8,9,11,14,15,17,26,31,35]$ but not all studies [12, $13,16,31,32,36]$. However, this influence of previous or recurrent stroke might depend on the etiology of PSD: the risk is increased when PSD is vascular in origin, but not when it is degenerative in origin [35].

\section{Hypoxic-Ischemic Disorders}

Hypoxic-ischemic disorders were found to increase the risk of delayed dementia in stroke patients $[31,36]$. Still, the association does not indicate causality and was not consistently found [12]. The category of hypoxic-ischemic disorders used is certainly too broad, including conditions that produce transient (seizure and syncope) and prolonged (heart failure and myocardial infarction) hypoxia. The association warrants further studies. 


\section{Radiological Data}

Silent Infarcts

In the first study evaluating the relationship between PSD and silent infarcts [4], the frequency of dementia increased with the number and size of silent infarcts, whereas another study did not find any relationship between silent infarcts and PSD [34]. Nevertheless, in this study, despite a long follow-up, the small number of subjects may have led to a lack of power of the statistical analysis. The presence of silent infarcts on CT performed in the acute phase of the stroke was actually found to be an independent predictor of PSD [12, 37].

\section{Cerebral Atrophy}

Cerebral atrophy is a predictor of PSD $[4,12,16,32$, $37,42]$. MTLA is more frequent in stroke patients with preexisting dementia [22] but also exists in nondemented ones and is associated with a higher risk [37, 40, 43]. Stroke patients with MTLA could have preclinical Alzheimer's disease (AD), clinically revealed by stroke, even if MTLA does not seem to be specific to AD and is also observed in $\mathrm{VaD}$ [44-46]. It remains to be determined to what extent the presence of MTLA is a risk factor for delayed PSD.

\section{White Matter Changes}

WMC probably play a role in the development of PSD $[4,6,12,16,37]$. The major confounding factors may, however, be the presence of cerebral atrophy and lacunar infarcts, which are associated with a higher frequency of both WMC and dementia and probably share a common pathogenesis with WMC.

\section{Functional Neuroimaging}

To our knowledge, there is no study with functional neuroimaging techniques, such as single-photon emission $\mathrm{CT}$, positron emission tomography, functional magnetic resonance imaging or spectroscopy, aiming to identify predictors of PSD in consecutive stroke patients.

\section{Etiology of PSD}

Only few data concerning the etiology of PSD are available. They almost all suggest that PSD is not always vascular in origin.

In the Rochester study [26], 1\% of patients with PSD were diagnosed as having $\mathrm{AD}$. The incidence of $\mathrm{AD}$ within 1 year was 2.6-fold higher in the stroke patients compared to the controls, followed by a $50 \%$ annual excess of
$\mathrm{AD}$ in the stroke cohort compared to the community for 25 years of observation. In another population-based study [2], about half of the cases were diagnosed as probable $\mathrm{VaD}$ because the dementia occurred immediately after stroke, while about half of the cases were considered as possible $\mathrm{VaD}$, since the dementia onset was insidious and occurred more than 4 months after the stroke onset. In the Framingham study [28], the majority of stroke subjects developed either $\mathrm{VaD}(51 \%)$ or mixed dementia (AD with $\mathrm{VaD}, 37 \%$ ).

Most available data concerning the etiology of PSD have been obtained in stroke cohorts, with neuropsychological evaluation performed within the first 3 months after stroke. Of the patients demented 3 months after stroke $[5,9,11,35] 19-39 \%$ were diagnosed as having $\mathrm{AD}+$ stroke because cognitive disturbances had been present prior to stroke, the remainder in most cases being diagnosed as having dementia directly related to vascular disease. However, in these studies $[5,9,11,35]$ a bias due to the absence of strict exclusion criteria for patients with undiagnosed prestroke dementia is possible. In the study of Barba et al. [10] patients with prestroke dementia were diagnosed using a standardized methodology, but the authors did not separate the patients with pre- and poststroke dementia in their analysis. They found $71 \%$ of patients with PSD to have probable VaD and 29\% to have possible $\mathrm{VaD}$, including $16 \%$ with mild-to-moderate mental impairment of insidious onset and a progressive course (probable AD) before the stroke and 9\% who showed a slow progression of cognitive decline after the stroke. Nevertheless, even after the exclusion of the patients with prestroke dementia using a standardized methodology [12], about one third of the patients with PSD were diagnosed as having $\mathrm{AD}$, always at the month 6 visit, while two thirds received the diagnosis of probable or possible $\mathrm{VaD}$.

Only 2 studies, both conducted in Asian countries [14, 16], did not confirm this high proportion of degenerative dementia in patients with PSD. However, in the first one [14] the population studied was about 10 years younger that the population evaluated in previous studies; in the second one [16] the diagnosis of $\mathrm{VaD}$ was based on DSM IV criteria, which are less specific than others [47].

From all these data we can conclude that PSD is not always vascular in origin, even if it occurs immediately after stroke. Only few data $[12,26,32]$ concerning delayed dementia are available, but they also suggest that delayed PSD is probably of vascular origin in some cases and of degenerative origin in others: $63 \%$ of patients with delayed PSD were diagnosed as having probable $\mathrm{VaD}$ and $37 \%$ as having possible $\mathrm{AD}[32]$. 


\section{Mechanisms of PSD}

PSD patients do not constitute a homogeneous group.

\section{Prestroke Dementia}

Prestroke dementia is frequent [21-25] and often undiagnosed $[21,22]$. In the absence of a systematic evaluation of prestroke cognitive status, many cases of PSD are certainly prestroke dementias. It follows that many of these could be degenerative in origin [21].

\section{'Pure' VaD}

Vascular lesions play a role in the development of PSD, and PSD is probably due to stroke alone under the following circumstances: (1) in young stroke patients who become demented after 1 or several strokes, (2) when the clinician has a high level of certainty that the cognitive functioning of the patient was normal before stroke, impaired immediately after and will not worsen over time or even slightly improve, (3) when the lesions are located in strategic areas and (4) when a specific vascular condition known to cause dementia (such as cerebral autosomal dominant angiopathy with subcortical infarcts and leukoencephalopathy) is proven by pathological data or a specific marker. It is important to notice that 'strategic' locations have been described in single cases or in small series [48-51]. Nevertheless, in case reports with first generations of $\mathrm{CT}$ scans, another vascular lesion of the brain cannot be excluded and may interfere with the neuropsychological profile [52]. Moreover, in elderly patients without follow-up the contribution of Alzheimer lesions cannot be excluded [53-55]. The concept of strategic stroke should therefore be revised with modern imaging techniques and a longer follow-up.

\section{The Multifactorial Origin of PSD}

Many cases of PSD are probably the consequence of the cumulative effect of vascular lesions, AD and WMC. The links between cerebrovascular disease and AD are close [54]. Elderly subjects without a history of stroke but with cognitive decline have a high risk of stroke [56]. The risk of $\mathrm{AD}$ is increased, with an earlier age at the onset of dementia, in subjects with a history of stroke, with a higher risk for those who also have vascular risk factors [57]. Alzheimer and vascular lesions of the brain are frequently associated at autopsy $[58,59]$. Patients with AD have some degree of vascular changes [60,61], which may cause cerebral hemorrhages or infarcts, lacunas and WMC. Shared risk factors of the 2 clinical entities may also be responsible for their co-occurrence. Besides advancing age, 1 of them might be the allele $\varepsilon 4$ of the apolipoprotein E gene [62], which is associated with an increased risk of cerebral infarct [63], with a greater progression of cognitive decline in old stroke patients with cognitive decline/no dementia [64] and perhaps also with an increased risk of $\mathrm{AD}$ [65]. However, no difference was found for the frequency of apolipoprotein $\mathrm{E} \varepsilon 4$ alleles and apolipoprotein E gene promoter polymorphisms between patients with and without PSD 3 months after stroke [66]. Arterial hypertension, smoking and increased intima-media thickness in the common carotid artery are also risk factors common to vascular diseases and $\mathrm{AD}$ [67].

WMC are related to strokes. They are frequent in $\mathrm{VaD}$ and are also found in $\mathrm{AD}$, especially with late onset. In healthy elderly subjects they are associated with subtle neuropsychological [68, 69] and behavioral changes [70]. WMC may contribute to dementia in stroke patients because they indicate an increased risk of stroke recurrence [71], and they lead to a subtle cognitive decline with the possible consequences of stroke lesions and even associated Alzheimer pathology [72]. Even if vascular lesion, Alzheimer pathology or WMC do not lead to dementia by themselves, their cumulative effect may reach the threshold of lesions required to produce dementia [54]. If a stroke, WMC or both occur in a patient with asymptomatic $\mathrm{AD}$, the period of preclinical $\mathrm{AD}$ may be shortened. In the nun study, among patients who met neuropathological criteria for $\mathrm{AD}$, those with brain infarcts had poorer cognitive functions and a higher prevalence of dementia than those without infarcts, while among patients who did not meet the neuropathological criteria for AD, brain infarcts were only weakly associated with poor cognitive functions and dementia [53], suggesting that stroke lesions may play a role in determining the presence and severity of the clinical symptoms of AD. This result is supported by another study [73], conducted on older catholic clergy, which found AD pathology and macroscopic cerebral infarctions to contribute additively to the likelihood of dementia, however, without evidence of an interaction between both. In patients included in the dementia substudy of Systolic Hypertension in Europe a beneficial effect of antihypertensive therapy on the risk of cognitive decline and of $\mathrm{AD}$ was shown [74]. This effect may result from the reduced incidence of infarcts by lowering of the blood pressure, which prevents the anticipation of the clinical expression of $\mathrm{AD}$ [75]. Moreover, it has been shown that previous cognitive decline - no dementia is a risk factor for PSD, suggesting that some 
diagnoses of PSD could be AD, subclinical before stroke, but revealed by stroke.

\section{Influence of PSD on Stroke Patients' Prognosis}

\section{Functional Outcome}

The few data published suggest that patients with PSD are functionally impaired and dependent in daily living activities $[4,5,10,14]$.

\section{Mortality}

Patients with dementia have a higher mortality rate, independently of the effects of age and comorbidities [76, 77]. The mortality rate is also increased in patients with PSD [42, 78-81], the relative risk of death ranging from 2.4 to 6.3. Many mechanisms may underlie this increased mortality rate. Dementia could be associated with a more severe vascular disease and a higher risk of complications [42], but the causes of death did not differ between demented and nondemented patients [79, 80], even though the number of vascular deaths tended to be higher in the group of demented patients [80] and was highest in the group with PSD considered as vascular in origin [79]. Another possibility is that dementia could be a worsening factor when an intercurrent disease occurs, either because of a decreased capacity to respond to aggressions or because demented patients receive less aggressive treatment [82-84]. Moreover, demented patients may be less compliant with the treatment regimens that are actually prescribed.

\section{Stroke Recurrence}

The data concerning the influence of PSD on the risk of stroke recurrence are controversial. Dementia diagnosed 3 months after stroke was associated with an increased risk of stroke recurrence of about 3 [85], suggesting that dementia may be a surrogate marker for multiple vascular risk factors that might augment the risk of recurrence. On the other hand, a less intensive management of stroke patients with dementia as well as their lack of compliance may also contribute to the increased risk of recurrence [86]. An argument in favor of this hypothesis is that the risk of stroke recurrence was not increased in patients with PSD when no difference in the treatment for stroke prophylaxis was observed between demented and nondemented patients [12]. Moreover, the presence of WMC could be a confounding factor, WMC being strongly associated with stroke recurrence [12].

\section{Treatments of PSD}

The management of PSD focuses on secondary prevention treatment with control of cerebrovascular risk factors. A better control could diminish the risk of cognitive decline by reducing the risk of stroke recurrence with an indirect effect on the clinical expression of the degenerative processes. However, the results of controlled hypertension trials are controversial [74, 87-90].

Another therapeutic approach is the cholinergic strategy. Vascular lesions may produce a cholinergic dysfunction due to ischemic damage of basal forebrain neurons or their projections, similar to that seen in AD [91]. In studies on cholinesterase inhibitors in patients with pure $\mathrm{VaD}$, the treatment showed to be effective in improving cognition and preventing functional deterioration [9295]. In addition, cholinergic agents should be beneficial in the third of PSD patients considered as having AD associated with stroke.

\section{Discussion}

Hospital- and community-based studies provide similar findings: a stroke doubles the risk of dementia, the risk is highest within the first months after stroke, as almost 1 patient out of 5 is demented, and the risk of delayed dementia (including AD) is also doubled after stroke. All published studies suggest that PSD adversely influences the vital and probably functional outcome. The following factors have been identified as associated with a higher risk of PSD: increasing age, prestroke loss of autonomy and cognitive decline/no dementia, diabetes mellitus, atrial fibrillation, and, from a radiological point of view, silent infarcts, global cerebral atrophy, MTLA and WMC. Previous stroke and stroke recurrence are also related to a higher risk of PSD. No clear conclusion concerning the influence of the stroke location and size can be drawn from the published studies. This is probably mainly due to the fact that PSD is not a disease but a syndrome, whose origin is in many cases multifactorial, with the intervention of stroke characteristics but also of WMC and underlying degenerative diseases. Indeed, about one third of PSD diagnoses are AD, and only two thirds of patients are diagnosed as having $\mathrm{VaD}$ (even in these patients an underlying degenerative disease often cannot be excluded). From that perspective the concept of PSD, supposed to help understand the pathophysiology of $\mathrm{VaD}$, has not been very useful. If the aim is to better comprehend the mechanism underlying $\mathrm{VaD}$, further studies are needed, 
carefully excluding patients with prestroke cognitive decline and poststroke AD. On the other hand, the concept of PSD has been valuable for patients who are followed up after a stroke, before the diagnostic workup allows a classification into vascular, degenerative and mixed dementia. The fact has been pointed out that dementia is very frequent in stroke patients, sometimes even present but undiagnosed before stroke. The concept of PSD has led to conduct trials in stroke patients whose secondary endpoint was cognitive outcome $[89,91]$ and could also be useful to focus on cognitive impairment rather than dementia because the former takes into account all the cognitive consequences of strokes, even if the criteria for dementia are not present. We should bear in mind that the true cognitive burden of strokes is underestimated, cognitive impairment without dementia being 3 times more frequent in patients who had a stroke than in strokefree controls [3].

\section{References}

-1 Prencipe M, Ferreti C, Casini AR, Santini M, Giubilei F, Culasso F: Stroke, disability, and dementia: results of a population survey. Stroke 1997;28:531-536.

$\checkmark 2$ Zhu L, Fratiglioni L, Guo Z, Basun H, Corder $\mathrm{EH}$, Winblad B, Viitanen M: Incidence of dementia in relation to stroke and the apolipoprotein $\mathrm{E} \varepsilon 4$ allele in the very old: findings from a population-based longitudinal study. Stroke 2000;31:53-60.

-3 Linden T, Skoog I, Fagerberg B, Steen B, Blomstrand $\mathrm{C}$ : Cognitive impairment and dementia 20 months after stroke. Neuroepidemiology 2004;23:45-52.

-4 Tatemichi TK, Foulkes MA, Mohr JP, Hewitt JR, Hier DB, Price TR, Wolf PA: Dementia in stroke survivors in the stroke data bank cohort: prevalence, incidence, risk factors and computed tomographic findings. Stroke 1990;21: 858-866.

$\checkmark 5$ Tatemichi TK, Desmond DW, Mayeux R, Paik M, Stern Y, Sano M, Remien RH, Williams JBW, Mohr JP, Hauser WA, Figueroa M: Dementia after stroke: baseline frequency, risks and clinical features in a hospitalized cohort. Neurology 1992;42:1185-1193.

-6 Andersen G, Vestergaard K, Ostergaard Riis J, Ingemen-Nielsen $\mathrm{M}$ : Intellectual impairment in the first year following stroke compared to an age-matched population sample. Cerebrovasc Dis 1996;6:363-369.

7 Censori B, Manara O, Agostinis C, Camerlingo M, Casto L, Galavotti B, Partziguian T, Servalli MC, Cesana B, Belloni G, Mamoli A: Dementia after first stroke. Stroke 1996;27:12051210 .

$>8$ Inzitari D, Di Carlo A, Pracucci G, Lamassa M, Vanni P, Romanelli M, Spolveri S, Adriani P, Meucci I, Landini G, Ghetti A: Incidence and determinants of poststroke dementia as defined by an informant interview method in a hospital-based stroke registry. Stroke 1998; 29:2087-2093.

-9 Pohjasvaara T, Erkinjuntti T, Ylikoski R, Hietanen M, Vataja R, Kaste M: Clinical determinants of poststroke dementia. Stroke 1998;29: $75-81$.
10 Barba R, Martinez-Espinoza S, RodriguezGarcia E, Pondal M, Vivancos J, Del Ser T: Poststroke dementia: clinical features and risk factors. Stroke 2000;31:1494-1501.

11 Desmond DW, Moroney JT, Paik MC, Sano M, Mohr JP, Aboumatar S, Tseng CL, Chan S, Williams JB, Remien RH, Hauser WA, Stern $\mathrm{Y}$ : Frequency and clinical determinants of dementia after ischemic stroke. Neurology 2000; 54:1124-1131.

12 Hénon H, Durieu I, Guerouaou D, Lebert F Pasquier F, Leys D: Post-stroke dementia: incidence and relationship with pre-stroke cognitive decline. Neurology 2001;57:1216-1222.

13 Madureira S, Guerreiro M, Ferro JM: Dementia and cognitive impairment three months after stroke. Eur J Neurol 2001;8:621-627.

14 Lin JH, Lin RT, Tai CT, Hsieh CL, Hsiao SF, Liu CK: Prediction of poststroke dementia. Neurology 2003;61:343-348.

15 Mok VC, Wong A, Lam WW, Fan YH, Tang WK, Kwok T, Hui AC, Wong KS: Cognitive impairment and functional outcome after stroke associated with small vessel disease. J Neurol Neurosurg Psychiatry 2004;75:560 566.

16 Tang WK, Chan SS, Chiu HF, Ungvari GS, Wong KS, Kwok TC, Mok V, Wong KT, Richards PS, Ahuja AT: Frequency and determinants of poststroke dementia. Stroke 2004;35: 930-935.

17 Zhou DH, Wang JY, Li J, Deng J, Gao C, Chen M: Study on frequency and predictors of dementia after ischemic stroke: the Chongqing stroke study. J Neurol 2004;251:421-427.

18 Rasquin SM, Verhey FR, van Oostenbrugge RJ, Lousberg R, Lodder J: Demographic and $\mathrm{CT}$ scan features related to cognitive impairment in the first year after stroke. J Neurol Neurosurg Psychiatry 2004;75:1562-1567.

19 Pohjasvaara T, Erkinjuntti T, Vataja R, Kaste $\mathrm{M}$ : Dementia three months after stroke: baseline frequency of different definitions of dementia in the Helsinki Stroke Aging Memory Study (SAM) cohort. Stroke 1997;28:785-792.

20 Desmond DW, Bagiella E, Moroney JT, Stern Y: The effect of patient attrition on estimates of the frequency of dementia following stroke. Arch Neurol 1998;55:390-394.
21 Hénon H, Pasquier F, Durieu I, Godefroy O, Lucas C, Lebert F, Leys D: Pre-existing dementia in stroke patients: baseline frequency, associated factors and outcome. Stroke 1997;28: 2429-2436.

22 Hénon H, Pasquier F, Durieu I, Pruvo JP, Leys D: Medial temporal lobe atrophy in stroke patients: relation to pre-existing dementia. J Neurol Neurosurg Psychiatry 1998;65:641-647.

-23 Pohjasvaara T, Mantyla R, Aronen HJ, Leskela M, Salonen O, Kaste M, Erkinjuntti T: Clinical and radiological determinants of prestroke cognitive decline in a stroke cohort. J Neurol Neurosurg Psychiatry 1999;67:742748 .

24 Barba R, Castro MD, del Mar Morin M, Rodriguez-Romero R, Rodriguez-Garcia E, Canton R, Del Ser T: Prestroke dementia. Cerebrovasc Dis 2001;11:216-224.

25 Klimkowicz A, Dziedzic T, Slowik A, Szczudlik A: Incidence of pre- and poststroke dementia: Cracow stroke registry. Dement Geriatr Cogn Disord 2002; 14:137-140.

-26 Kokmen E, Whisnant JP, O'Fallon WM, Chu $\mathrm{CP}$, Beard CM: Dementia after ischemic stroke: a population-based study in Rochester, Minnesota (1960-1984). Neurology 1996;46: 154-159.

27 Zhu L, Fratiglioni L, Guo Z, Agüero Torres H, Winblad B, Viitanen M: Association of stroke with dementia, cognitive impairment and functional disability in the very old: a population-based study. Stroke 1998;29:2094-2099.

28 Ivan CS, Seshadri S, Beiser A, Au R, Kase CS, Kelly-Hayes M, Wolf PA: Dementia after stroke: the Framingham study. Stroke 2004; 35:1264-1268.

29 Srikanth VK, Anderson JF, Donnan GA, Saling MM, Didus E, Alpitsis R, Dewey HM, Macdonell RA, Thrift AG: Progressive dementia after first-ever stroke: a community-based follow-up study. Neurology 2004;63:785792.

30 Tatemichi TK, Paik M, Bagiella E, Desmond DW, Stern Y, Sano M, Hauser WA, Mayeux $\mathrm{R}$ : Risk of dementia after stroke in a hospitalized cohort: results of a longitudinal study. Neurology 1994;44:1885-1891. 
-31 Desmond DW, Moroney JT, Sano M, Stern Y: Incidence of dementia after ischemic stroke: results of a longitudinal study. Stroke 2002;33: 2254-2262.

-32 Altieri M, Di Piero V, Pasquini M, Gasparini M, Vanacore N, Vicenzini E, Lenzi GL: Delayed poststroke dementia: a 4-year follow-up study. Neurology 2004;62:2193-2197.

>33 Ballard C, Stephens S, Kenny R, Kalaria R, Tovee M, O'Brien J: Profile of neuropsychological deficits in older stroke survivors without dementia. Dement Geriatr Cogn Disord 2003; 16:52-56.

-34 Bornstein NM, Gur AY, Treves TA, ReiderGroswasser I, Aronovich BD, Klimovitzky SS, Varssano D, Korczyn AD: Do silent brain infarctions predict the development of dementia after first ischemic stroke? Stroke 1996;27: 904-905.

$\checkmark 35$ Tatemichi TK, Desmond DW, Paik M, Figueroa M, Gropen TI, Stern Y, Sano M, Remien R, Williams JB, Mohr JP, et al: Clinical determinants of dementia related to stroke. Ann Neurol 1993;33:568-575.

-36 Moroney JT, Bagiella E, Desmond DW, Paik MC, Stern Y, Tatemichi TK: Risk factors for incident dementia after stroke: the role of hypoxic and ischemic disorders. Stroke 1996; 27:1283-1289.

-37 Pohjasvaara T, Mantyla R, Salonen O, Aronen HJ, Ylikoski R, Hietanen M, Kaste M, Erkinjuntti T: MRI correlates of dementia after clinical ischemic stroke. J Neurol Sci 2000;181: 111-117.

-38 Mielke R, Herholz K, Grond M, Kessler J, Heiss WD: The severity of vascular dementia is related to the volume of metabolically impaired tissue. Arch Neurol 1992;49:909-913.

-39 Roman GC, Tatemichi TK, Erkinjuntti T, Cummings JL, Masdeu JC, Garcia JH, Amaducci L, Orgogozo JM, Brun A, Hofman A, et al: Vascular dementia: diagnostic criteria for research studies. Report of the NINDSAIREN International Workshop. Neurology 1993;43:250-260.

-40 Ballard CG, Burton EJ, Barber R, Stephens S, Kenny RA, Kalaria RN, O'Brien JT: NINDS AIREN neuroimaging criteria do not distinguish stroke patients with and without dementia. Neurology 2004;63:983-988.

-41 Adams HP Jr, Bendixen BH, Kappelle LJ, Biller J, Love BB, Gordon DL, Marsh III EE, and the TOAST investigators: Classification of subtypes of acute ischemic stroke: definitions for use in a multicenter clinical trial. Stroke 1993; 24:35-41.

42 Tatemichi TK, Paik M, Bagiella E, Desmond DW, Pirro M, Hanzawa LK: Dementia after stroke is a predictor of long-term survival. Stroke 1994;25:1915-1919.

43 Cordoliani-Mackowiak MA, Hénon H, Pruvo JP, Pasquier F, Leys D: Poststroke dementia: the influence of hippocampal atrophy. Arch Neurol 2003;60:565-590.
44 Jobst KA, Barnetson LP, Shepstone BJ: Accurate prediction of histologically confirmed Alzheimer's disease and the differential diagnosis of dementia: the use of NINCDS-ADRDA and DSMIII-R criteria, SPECT, X-ray CT and Apo E4 in medial temporal lobe dementia. Int Psychogeriatr 1998;10:271-302.

45 Laakso MP, Partanen K, Riekkinen P, Lehtovirta M, Helkala EL, Hallikainen M, Hanninen T, Vainio P, Soininen H: Hippocampal volumes in Alzheimer's disease, Parkinson's disease with and without dementia, and in vascular dementia: an MRI study. Neurology 1996; 46:678-681

46 Fein G, Di Sclafani V, Tanabe J, Cardenas V, Weiner MW, Jagust WJ, Reed BR, Norman D, Schuff N, Kusdra L, Greenfield T, Chui H: Hippocampal and cortical atrophy predict dementia in subcortical ischemic vascular disease. Neurology 2000;55:1626-1635.

47 Gold G, Bouras C, Canuto A, Bergallo MF, Herrmann FR, Hof PR, Mayor PA, Michel JP, Giannakopoulos P: Clinicopathological validation study of four sets of clinical criteria for vascular dementia. Am J Psychiatry 2002;159: 82-87.

48 Benson DF, Cummings JL: Angular gyrus syndrome simulating Alzheimer's disease. Arch Neurol 1982;39:616-620.

49 Alexander MP, Freedman M: Amnesia after anterior communicating artery aneurysm rupture. Neurology 1984;34:752-757.

50 Ott BR, Saver JL: Unilateral amnesic stroke: six new cases and a review of the literature. Brain 1993;24:1033-1042.

51 Bhatia KP, Marsden CD: The behavioural and motor consequences of focal lesions of the basal ganglia in man. Brain 1994;117:859-876.

52 Godefroy O, Rousseaux M, Pruvo JP, Cabaret M, Leys D: Neuropsychological changes related to unilateral lenticulostriate infarcts. J Neurol Neurosurg Psychiatry 1994;57:480-485.

53 Snowdon DA, Greiner LH, Mortimer JA, Riley KP, Greiner PA, Markesbery WR: Brain infarction and the clinical expression of Alzheimer disease: the nun study. JAMA 1997; 277:813-817.

54 Pasquier F, Leys D: Why are stroke patients prone to develop dementia? J Neurol 1997; 244:135-142.

55 Pasquier F, Leys D, Scheltens P: The influence of coincidental vascular pathology on symptomatology and course of Alzheimer's disease. J Neural Transm 1998;53:117-127.

56 Ferrucci L, Guralnik JM, Salive ME, Pahor M, Corti MC, Baroni A, Havlik RJ: Cognitive impairment and risk of stroke in the older population. J Am Geriatr Soc 1996;44:237-241.

57 Honig LS, Tang MX, Albert S, Costa R, Luchsinger J, Manly J, Stern Y, Mayeux R: Stroke and the risk of Alzheimer disease. Arch Neurol 2003;60:1707-1712.

58 Ince PG, McArthur FK, Bjertness E, Torvik A, Candy JM, Edwardson JA: Neuropathological diagnoses in elderly patients in Oslo: Alzheimer's disease, Lewy body disease and vascular lesions. Dementia 1995;6:162-168.
59 Victoroff J, Mack WJ, Lyness SA, Chui HC: Multicenter clinicopathological correlation in dementia. Am J Psychiatry 1995;152:14761484.

60 Ellis RJ, Olichney JM, Thal LJ, Mirra SS, Morris JC, Beekly D, Heyman A: Cerebral amyloid angiopathy in the brain of patients with Alzheimer's disease: the CERAD experience, part XV. Neurology 1996;46:1592-1596.

61 Brun A, Englund E: A white matter disorder in dementia of the Alzheimer type: a pathoanatomical study. Ann Neurol 1986;19:253-262.

62 Terry JG, Howard G, Mercuri M, Bond MG, Crouse JR 3rd: Apolipoprotein E polymorphism is associated with segment-specific extracranial carotid artery intima-media thickening. Stroke 1996;27:1755-1759.

63 Wilson PW, Myers RH, Larson MG, Ordovas JM, Wolf PA, Schaefer EJ: Apolipoprotein E alleles, dyslipidemia and coronary heart disease: the Framingham offspring study. JAMA 1994;272:1666-1671

64 Ballard CG, Morris CM, Rao H, O’Brien JT, Barber R, Stephens S, Rowan E, Gibson A, Kalaria RN, Kenny RA: APOE epsilon4 and cognitive decline in older stroke patients with early cognitive impairment. Neurology 2004;63:1399-1402.

-65 Pedro-Botet J, Senti M, Nogues X, Rubies-Prat J, Roquer J, D’Olhaberriague L, Olive J: Lipoprotein and apolipoprotein profile in men with ischemic stroke: the role of lipoprotein (a), triglyceride-rich lipoproteins and apolipoprotein E polymorphism. Stroke 1992;23:1556-1562.

-66 Arpa A, del Ser T, Goda G, Barba R, Bornstein $\mathrm{B}$ : Apolipoprotein E, angiotensin-converting enzyme and $\alpha_{1}$-antichymotrypsin genotypes are not associated with post-stroke dementia. J Neurol Sci 2003;210:77-82.

67 Hofman A, Ott A, Breteler MM, Bots ML, Slooter AJ, van Harskamp F, van Duijn CN, Van Broeckhoven C, Grobbee DE: Atherosclerosis, apolipoprotein E, and prevalence of dementia and Alzheimer's disease in the Rotterdam study. Lancet 1997;349:151-154.

68 Skoog I, Berg S, Johansson B, Palmertz B, Andreasson LA: The influence of white matter lesions on neuropsychological functioning in demented and non-demented 85-year-olds. Acta Neurol Scand 1996;93:142-148.

69 DeCarli C, Murphy DG, Tranh M, Grady CL, Haxby JV, Gillette JA, Salerno JA, GonzalesAviles A, Horwitz B, Rapoport SI, et al: The effect of white matter hyperintensity volume on brain structure, cognitive performance and cerebral metabolism of glucose in 51 healthy adults. Neurology 1995;45:2077-2084.

70 Tarvonen-Schroder S, Roytta M, Raiha I, Kurki T, Rajala T, Sourander L: Clinical feature of leukoaraiosis. J Neurol Neurosurg Psychiatry 1996;60:431-436.

71 Hénon H, Vroylandt P, Durieu I, Pasquier F, Leys D: Leukoaraiosis more than dementia is a predictor of stroke recurrence. Stroke 2003; 34:2935-2940. 
72 Leys D, Hénon H, Pasquier F: White matter changes and post-stroke dementia. Dement Geriatr Cogn Disord 1998;9:25-29.

-73 Schneider JA, Wilson RS, Bienias JL, Evans DA, Bennett DA: Cerebral infarctions and the likelihood of dementia from Alzheimer disease pathology. Neurology 2004;62:1148-1155.

74 Forette F, Seux ML, Staessen JA, Thijs L, Birkenhager WH, Babarskiene MR, Babeanu S, Bossini A, Gil-Extremera B, Girerd X, Laks T, Lilov E, Moisseyev V, Tuomilehto J, Vanhanen H, Webster J, Yodfat Y, Fagard R: Prevention of dementia in the randomised doubleblind placebo-controlled Systolic Hypertension in Europe (Syst-Eur) trial. Lancet 1998;352: 1347-1351.

77 Leys D, Pasquier F: Prevention of dementia: Syst-Eur trial. Lancet 1999;353:236-237.

76 Aevarsson O, Svanborg A, Skoog I: Seven-year survival rate after 85 years. Arch Neurol 1998; 55:1226-1232.

77 Baldereschi M, Di Carlo A, Maggi S, Grigoletto F, Scarlato G, Amaducci L, Inzitari D: Dementia is a major predictor of death among the Italian elderly. ILSA Working Group. Italian Longitudinal Study on Aging. Neurology 1999;52:709-713.

-78 Woo J, Kay R, Yuen YK, Nicholls MG: Factors influencing long-term survival and disability among three-month stroke survivors. Neuroepidemiology 1992;11:143-150.

-79 Hénon H, Durieu I, Lebert F, Pasquier F, Leys $\mathrm{D}$ : Influence of prestroke dementia on early and delayed mortality in stroke patients. $\mathrm{J}$ Neurol 2003;250:10-16.

-80 Desmond DW, Moroney JT, Sano M, Stern Y: Mortality in patients with dementia after ischemic stroke. Neurology 2002;59:537-543.
-81 Barba R, Morin MD, Cemillan C, Delgado C, Domingo J, Del Ser T: Previous and incident dementia as risk factors for mortality in stroke patients. Stroke 2002;33:1993-1998.

82 Rockwood K, Ebly E, Hachinski V, Hogan D: Presence and treatment of vascular risk factors in patients with vascular cognitive impairment. Arch Neurol 1997;54:33-39.

83 Gurwitz JH, Monette J, Rochon PA, Eckler MA, Avorn J: Atrial fibrillation and stroke prevention with warfarin in the long-term care setting. Arch Intern Med 1997;157:978-984.

84 Krumholz HM, Radford MJ, Ellerbeck EF, Hennen J, Meehan TP, Petrillo M, Wang Y, Jencks SF: Aspirin for secondary prevention after acute myocardial infarction in the elderly: prescribed use and outcomes. Ann Intern Med 1996;124:292-298.

85 Moroney JT, Bagiella E, Tatemichi TK, Paik MC, Stern Y, Desmond DW: Dementia after stroke increases the risk of long-term stroke recurrence. Neurology 1997;48:1317-1325.

86 Moroney JT, Tseng CL, Paik MC, Mohr JP, Desmond DW: Treatment for the secondary prevention of stroke in older patients: the influence of dementia status. J Am Geriatr Soc 1999;47:824-829.

87 Starr JM, Whalley LJ, Deary IJ: The effects of antihypertensive treatment on cognitive function: results from the HOPE study. J Am Geriatr Soc 1996;44:411-415.

88 Tzourio C, Anderson C, Chapman N, Woodward M, Neal B, MacMahon S, Chalmers J, Progress Collaborative Group: Effects of blood pressure lowering with perindopril and indapamide therapy on dementia and cognitive decline in patients with cerebrovascular disease. Arch Intern Med 2003;163:1069-1075.
89 SHEP Cooperative Research Group: Prevention of stroke by antihypertensive drug treatment in older persons with isolated systolic hypertension: final results of the Systolic Hypertension in the Elderly Program (SHEP). J Am Med Assoc 1991;265:3255-3264.

90 Lithell H, Hansson L, Skoog I, Elmfeldt D, Hofman A, Olofsson B, Trenkwalder P, Zanchetti A, SCOPE Study Group: The Study on Cognition and Prognosis in the Elderly (SCOPE): principal results of a randomized double-blind intervention trial. J Hypertens 2003;21:875-886.

91 Gottfries C-G, Blennow K, Karlsson I, Wallin A: The neurochemistry of vascular dementia. Dementia 1994;5:163-167.

92 Black S, Roman GC, Geldmacher DS, Salloway S, Hecker J, Burns A, Perdomo C, Kumar D, Pratt R, Donepezil 307 Vascular Dementia Study Group: Efficacy and tolerability of donepezil in vascular dementia: positive results of a 24-week, multicenter, international, randomized, placebo-controlled clinical trial. Stroke 2003;34:2323-2330.

93 Wilkinson D, Doody R, Helme R, Taubman K, Mintzer J, Kertesz A, Pratt RD, Donepezil 308 Study Group: Donepezil in vascular dementia: a randomized, placebo-controlled study. Neurology 2003;61:479-486.

94 Kurz AF, Erkinjuntti T, Small GW, Lilienfeld $\mathrm{S}$, Damaraju CV: Long-term safety and cognitive effects of galantamine in the treatment of probable vascular dementia or Alzheimer's disease with cerebrovascular disease. Eur J Neurol 2003; 10:633-640.

95 Bullock R: Cholinesterase inhibitors and vascular dementia: another string to their bow? CNS Drugs 2004;18:79-92. 